\title{
Citric acid and clove essential oil as alternatives to chlorine compounds on sanitization of apples
}

\author{
Gabriel Lessa Moncioso ${ }^{1} \oplus$, Bárbara Morandi Lepaus ${ }^{1} \oplus$, \\ Jhenifer de Souza Couto Oliveira ${ }^{1} \mathbb{D}$, Jackline Freitas Brilhante de São José ${ }^{1 *} \mathbb{B}$ \\ 1 Universidade Federal do Espírito Santo, Vitória, ES, Brasil. E-mail: gabrielmoncioso@hotmail.com; barbaralepaus@hotmail.com; jhenifersco@hotmail.com; jackline.jose@ufes.br
}

ABSTRACT: Sanitization is a crucial step for the microbiological control of ready-to-eat fruits. Chlorinated compounds are commonly used, but there is concern with their replacement due to their adverse effects on the environment and on public health. The aim was to assess the effect of sanitization treatments (with $1 \%$ citric acid and $0.5 \%$ clove essential oil - applied in combination or in separate) on the microbiological and physicochemical quality of apples. The sanitization step consisted in immersing of apple $(160 \mathrm{~g})$ in $500 \mathrm{~mL}$ of sanitizer solutions for 5 minutes. $200 \mathrm{mg} \mathrm{L}^{-1}$ sodium hypochlorite solution was used as reference treatment. Non-sanitized apples formed the control group. The presence of aerobic mesophilic bacteria, yeast and mold was analyzed, as well as $\mathrm{pH}$, total titratable acidity and total soluble solids in apples after they were subjected to the treatments. Alternative treatments showed similar or better results for aerobic mesophilic bacteria, and yeast and mold reduction than sodium hypochlorite. The assessed physicochemical parameters did not evidence any impairment. The treatment combining citric acid $1 \%$ and clove essential oil $0.5 \%$ was the most efficient one among all the tested sanitizers and it showed the potential to be used during the sanitization.

Key words: eugenol; food safety; sanitization

\section{Ácido cítrico e óleo essencial de cravo como alternativas aos compostos clorados na sanitização de maçãs}

RESUMO: A sanitização é uma etapa crucial para controle microbiológico de frutas prontas para consumo. Os compostos clorados são comumente utilizados, mas há intenção de substituição deste produto devido aos possíveis efeitos adversos no meio ambiente e na saúde. Avaliou-se o efeito dos tratamentos de sanitização (com 1\% de ácido cítrico e 0,5\% de óleo de cravo-da-índia - aplicados em combinação ou isoladamente) na qualidade microbiológica e físico-química de maçãs. A etapa de sanitização consistiu na imersão de maçã (160 g) em $500 \mathrm{~mL}$ de soluções sanitizantes por 5 minutos. A solução de hipoclorito de sódio $200 \mathrm{mg} \mathrm{L}^{-1}$ foi usada como tratamento referência. Maçãs não sanitizadas foram utilizadas com controle. Foram analisadas a presença de bactérias mesófilas aeróbias e fungos filamentosos e leveduras. Foram realizadas também análises de $\mathrm{pH}$, acidez titulável total e sólidos solúveis totais em maçãs após a aplicação da sanitização. Os tratamentos alternativos proporcionaram resultados similares ou mais eficientes quanto à redução de contagem de bactérias mesófilas aeróbias e de fungos filamentosos e leveduras em comparação com a solução de hipoclorito de sódio. Os tratamentos avaliados não influenciaram significativa nos parâmetros fisico-químicos estudados. Ácido cítrico 1\% combinado ao óleo essencial de cravo-da-índia 0,5\% foi o mais eficiente entre os tratamentos avaliados e apresentou potencial para uso na sanitização de maçãs.

Palavras-chave: eugenol; segurança dos alimentos; sanitização

\footnotetext{
* Jackline Freitas Brilhante de São José - E-mail: jackline.jose@ufes.br (Corresponding author)

Associate Editor: Severino Matias de Alencar
} 


\section{Introduction}

Brazilian fruits are traded worldwide given their diversity and modern processing procedures, as well as the increasing quality levels in fruits' production and industrialization. Some areas in Brazil present favorable climate conditions for apple production, and it turns this fruit's cultivation into an important economic activity in the country. Apples are one of the favorite Brazilian consumers' fruits; moreover, they are among the most exported ones in Brazil (Anuário Brasileiro da Maçã, 2019). Apples are more often consumed with the peel; therefore, inappropriate fruit washing, and sanitization could expose consumers to contamination risks, such as chemical (pesticide residues) or microbiological (microorganisms on their surface) risks. Consumers' interest in healthy and wellbalanced diets has increased and this fact has encouraged a greater demand for foods such as fresh fruits and vegetables and ready-to-eat products (Weng et al., 2016; Alenyorege et al., 2019). It is essential to adopt good manufacturing practices throughout the processing chain to assure products' microbiological safety. When it comes to fresh and ready-toeat fruits, sanitization is the key step towards offering a safe unprocessed product with high nutritional value and sensory quality, although without losing the products' natural features (Weng et al., 2016; Alenyorege et al., 2019).

Chemical agents commonly used in fruit sanitization include chlorine-based products; such as sodium hypochlorite. This product is the most used one, presents easy preparation and application, remains effective at different concentrations and ensure the microbiological quality of minimally processed food (Weng et al., 2016; Lippman et al., 2020). However, chlorinated sanitizers can lead to bacterial resistance and adaptation to chlorine-based products. Moreover, they are potentially corrosive and can damage handlers' skin, mucosa, and airways. In addition, reports in the literature have highlighted the likely hyper chlorination of wastewater after the sodium hypochlorite treatment. The association between chlorinated sanitizers and high organic content in fruits is another concern, since it can result in high concentrations of trihalomethanes and other environmentally toxic byproducts (Poimenidou et al. 2016; Veloso et al., 2020; Lippman et al., 2020). In this sense, some European countries have already banned these compounds from fruit and vegetable sanitization (Lippman et al., 2020) since chlorinated compounds became a public health concern and their use is no longer recommended.

Organic acids and essential oils (EO) are among the currently assessed sanitizer alternatives since they act as natural antimicrobial and can be applied to food. The organic lactic, acetic, benzoic, propionic, and citric acids are already commonly used in the food industry (Chatterjee \& Abraham, 2018). On the other hand, EOs are secondary metabolites of plants and are extracted from several plant materials (leaves, roots, barks, flowers, stem, etc.). They are used as natural preservative in food; however, studies focused on testing their use as sanitizers remain scarce. Evidence in the literature have shown some safe and effective treatments based on the use of organic acids and essential oils during the sanitization step (Beraldo et al., 2013; Oulkheir et al., 2017; Veloso et al., 2020). Therefore, the present study aimed to investigate the microbiological and physicochemical quality of apples when subjected to different sanitizing procedures. We aimed to verify three hypotheses in this study: 1) citric acid and clove essential oil show similar or better effectiveness in the disinfection than the chlorine-based sanitizer; ii) combination of citric acid and clove essential oils would improve the chemical sanitizer efficiency; iii) treatments would did not affect physicochemical properties.

\section{Materials and Methods}

\section{Experimental design}

This research was conducted from February to March of 2019. Experimental study based on a completely randomized design with three repetitions and in duplicate. Investigations were performed at the Microbiology Laboratory of the Pharmaceutical Sciences Department and at the Food Analysis Laboratory of the Interprofessional Clinic Interprofessional School in Health of Federal University of Espírito Santo, Brazil.

\section{Sample collection}

Apple samples (Malus domestica cv. Fuji) were purchased at the local market, in Vitória City, Espírito Santo State - Brazil. They were taken to laboratory in isothermal boxes and stored at $7{ }^{\circ} \mathrm{C}$ for 24 hours, at most, before processing. Fruits were selected before the treatment; the damaged or rotten ones were discarded. Next, the ones selected for the experiment were washed in running water to remove the dirt adhered to their peel. Then, apples were drained for 10 minutes in protected place.

\section{Preparation of sanitization solutions and treatments}

The effects of the following sanitizing agents were evaluated: $0.5 \%$ clove essential oil (CEO) (Syzygium aromaticum) (Ferquimica ${ }^{\circledR}$ ), 1\% citric acid (Dinâmica ${ }^{\circledR}$ ); as well as the association of both. Solutions containing EO were prepared with surfactant Tween 80 (Dynamics $^{\circledR}$ ) at $0.5 \%$ concentration to allow water homogenization. The homogenization was conducted in a glass bottle, previously sterilized, on magnetic stirrer. The treatment with sodium hypochlorite - $200 \mathrm{mg} \mathrm{L}^{-1}$ - (Hidrosteril ${ }^{\oplus}$ ) was adopted as parameter of reference. Apples washed in running water without the addition of the sanitizer were selected as control for the initial contamination level evaluation. All solutions were prepared in distilled water. The sanitization step consisted of immersing one apple (approximately $160 \mathrm{~g}$ ) for each $500 \mathrm{~mL}$ of solution, which was prepared right before its use, for $5 \mathrm{~min}$ at $23 \pm 1{ }^{\circ} \mathrm{C}$. The treatments were carried out in $4 \mathrm{~L}$ of sanitizing solution. Concentrations and exposure time followed parameters found in previous experiments and in data available in the literature (Abdollahzadeh et al.,2014; AlRousan et al., 2018; Lepaus et al., 2020). The analyzes were carried out immediately after the sanitization treatments. 


\section{Microbiological analysis}

In total, $25 \mathrm{~g}$ of each apple sample were rinsed with tap water and homogenized in $225 \mathrm{~mL}$ of $0.1 \%$ sterilized peptone water after the treatment applied to generate $10^{-1}$ dilution of sample and appropriate serial dilutions were prepared (Downes \& Ito, 2001). Aliquots from each dilution were transferred to specific culture media to determine each microbial group. Aliquot plating of two dilutions was performed in duplicate and the results were expressed in log of colony-forming units per gram $\left(\log \mathrm{CFU} \mathrm{g}{ }^{-1}\right)$.

\section{Evaluation of apples' natural microbial contamination}

Aerobic mesophilic bacteria determination was performed through the pour plating technique in standard plate counting agar (Himedia ${ }^{\circledR}$ ) - which was molten and kept at $45{ }^{\circ} \mathrm{C}$ - by using $1 \mathrm{~mL}$ of the previously prepared dilutions. Plates were incubated at inverted position at $35^{\circ} \mathrm{C}$ for $48 \mathrm{~h}$ after medium solidification. The aliquot of $0.1 \mathrm{~mL}$ of sample dilutions was inoculated on the dry surface of potato dextrose agar $\left(\right.$ Himedia ${ }^{\circledR}$ ) - which was acidified at $\mathrm{pH} 3.5$ - to count yeasts and mold. Plates were incubated at non-inverted position at $25 \pm 1{ }^{\circ} \mathrm{C}$ for 5 to 7 days.

\section{Physicochemical analysis}

Evaluation of $\mathrm{pH}$, total titratable acidity and total soluble solids in apples after treatments

The $\mathrm{pH}$, total titratable acidity, and total soluble solids content were determined according to the AOAC (2016). $\mathrm{pH}$ measurements were taken in previously Total titratable acidity (TTA) were expressed as \% of malic acid. Total soluble solids (TSS) content was determined in analog refractometer (Instrutherm ${ }^{\circledR}$, Freguesia do Ó, São Paulo, Brazil) at $25^{\circ} \mathrm{C}$ and results were expressed in ${ }^{\circ}$ Brix.

\section{Evaluation of sanitizing solutions' $\mathrm{pH}$}

The $\mathrm{pH}$ of each sanitizing solution was determined in digital potentiometer (Tecnopon ${ }^{\circledR}$, mPA210, Piracicaba, São Paulo, Brazil). To conduct this analyse $50 \mathrm{~mL}$ of solution were prepared right before the analysis.

\section{Statistical analysis}

Data were analyzed in InfoStat Statistical Software (student version 2012, Cordoba National University, Argentina). Results were subjected to analysis of variance (ANOVA); Tukey's test was conducted at $5 \%$ of probability.

\section{Results and Discussion}

Treatment efficiency to reduce apples' natural microbiological contamination

The treatments significantly reduced $(p \leq 0.05)$ the initial contamination by all microorganisms analyzed in non-sanitized apple samples (Table 1).

Fruits are naturally contaminated by microorganisms, but the initial microbiological load can change depending on planting, harvesting, transportation and storage conditions (Lopez et al., 2018). The sodium hypochlorite treatment adopted in the current study reduced the number of aerobic mesophilic bacteria, and yeasts and mold to 1.18 and 0.72 $\log$ CFU g ${ }^{-1}$, respectively, in the non-sanitized samples. Citric acid (CA) sanitization showed aerobic mesophilic bacteria, and yeast and mold reduction to 1.57 and $1.53 \log C F U g^{-1}$, respectively. The treatment with clove essential oil (CEO) reduced the amount of aerobic mesophilic bacteria and of the fungi group to 1.84 and $1.64 \log$ CFU g ${ }^{-1}$, respectively. Samples subjected to the combined treatment $(C A+C E O)$ reduced $2.97 \log _{\text {CFU g}}{ }^{-1}$ and $2.46 \log _{\text {CFU g}}{ }^{-1}$ in the amount of aerobic mesophilic bacteria and mold and yeasts, respectively.

Reductions resulting from the chlorinated treatment were lower than the ones recorded after the application of the adopted alternative strategies. The number of microorganisms in apples sanitized with sodium hypochlorite was statistically similar that observed for the CA and CEO treatments ( $p$ $>0.05)$. However, samples treated with the chlorinated compound were the only ones presenting microbial groups statistically like those of the non-sanitized sample ( $p>$ 0.05). Sodium hypochlorite is an efficient sanitizer for food decontamination; however, in addition to quality of the water, and to the presence of inorganic salts and of organic material (Hung et al., 2017), chemical agent efficiency depends on the sanitized matrix type.

Organic acids such as the propionic, acetic, lactic, malic, and citric (at $1 \%$ and $2 \%$ ) ones have shown high potential to reduce Escherichia coli 0157:H7 and Salmonella Typhimurium in apples and lettuce (Park et al., 2011). Another study assessed apples sanitized with $2 \%$ lactic acid and showed performance similar, or superior, to that of chlorinated compounds to reduce E. coli $0157: \mathrm{H} 7$ and S. Typhimurium (Tian et al., 2013). Moreover, organic acids (1\% lactic or $2 \%$ acetic acid) have shown reduction rates similar to, or higher than, that of chlorinated compounds (of natural microflora)

Table 1. Means and standard deviation $\left(\log C F U ~ g^{-1}\right)$ of natural microbiota found on non-sanitized apples and of apples subjected to different sanitization treatments, for 5 minutes.

\begin{tabular}{ccc}
\hline Treatment & Aerobic mesophiles & \multicolumn{2}{c}{ Yeasts and Mold } \\
\cline { 2 - 3 } & \multicolumn{1}{c}{$\log$ CFU $\mathbf{~ g}^{\mathbf{1} \pm \text { Standard Deviation }}$} \\
\hline No Sanitizer & $4.53 \pm 0.24^{\mathrm{a}}$ & $4.82 \pm 0.16^{\mathrm{a}}$ \\
Sodium hypochlorite 200mg L-1 & $3.35 \pm 0.55^{\mathrm{bb}}$ & $4.10 \pm 0.16^{\mathrm{ab}}$ \\
Citric acid 1\% & $2.96 \pm 0.66^{\mathrm{b}}$ & $3.29 \pm 0.36^{\mathrm{bc}}$ \\
Clove essential oil 0.5\% & $2.69 \pm 0.56^{\mathrm{bc}}$ & $3.18 \pm 0.48^{\mathrm{bc}}$ \\
\hline Citric acid 1\% + Clove essential oil 0.5\% & $1.56 \pm 0.27^{\mathrm{c}}$ & $2.36 \pm 0.59^{\mathrm{c}}$ \\
\hline
\end{tabular}

* Different letters in the same column indicate statistically significantly difference in the Tukey test at $p \leq 0.05$. 
to reduce Salmonella enterica Enteritidis in strawberries, cucumbers and rocket leaves (Lepaus et al., 2020). The minimum inhibitory concentration of clove EO and cinnamon EO necessary to make Gram-positive (Staphylococcus aureus and Listeria monocytogenes) and Gram-negative (E. coli and Salmonella sp.) bacteria inactive was lower than that of hypochlorite sodium (Beraldo et al., 2013). Treviso leaves sanitized with cinnamon EO did not achieve satisfactory reduction in contamination by Listeria monocytogenes. On the other hand, samples treated with citric acid $\left(5000 \mathrm{mg} \mathrm{L}^{-1}\right)$ have recorded reduction by $1.22 \mathrm{log}_{\mathrm{CFU} \mathrm{g}} \mathrm{g}^{-1}$ in the number of this pathogen; the EO/organic acids (acetic, malic, citric, or lactic) combination led to greater reductions (Kang et al., 2018).

Citric, lactic and acetic acids are acknowledged as natural and safe antimicrobial agents and the inactivation mechanism is triggered by undissociated organic acids and weak acids, such as the aforementioned ones. This inactivation derives from $\mathrm{pH}$ reduction in the solution, which damages cell walls in microorganisms, inhibits enzymatic reactions and changes protein and DNA structures (Wang et al., 2015). These organic acids can easily penetrate cell walls in microorganisms, intracellular $\mathrm{pH}$ reduction and organic acid accumulation (Wang et al., 2014). Essential oils are mixtures of volatile organic compounds accounting for plant flavor and aroma (Veloso et al., 2020); they have low toxicity, which turns them into environment-friendly compounds (Marques et al., 2019). Clove (Syzygium aromaticum) presents eugenol, which is the main antimicrobial agent; it disrupts the cytoplasmic membrane, releases the ions and causes excessive loss of cellular components, a fact that leads to microbial cell death (Devi et al., 2010).

A previous study conducted by Dunn et al. (2019) has found that clove EO at $0.5 \%$ was more effective in reducing Salmonella in bell peppers than sodium hypochlorite $(200 \mathrm{mg}$ $\left.\mathrm{L}^{-1}\right)$; it recorded microbial count below the threshold detection $\left(<1 \mathrm{CFU} 10 \mathrm{~g}^{-1}\right.$ ). Based on such result, CEO has the potential to replace the chlorinated compound in sanitization processes. Lettuce leaves sanitized with thyme EO (250 mg L-1) showed similar aerobic mesophilic bacterial numbers as the ones treated with chlorinated compound $\left(120 \mathrm{mg} \mathrm{L}^{-1}\right)$ (Siroli et al., 2017).

Synergistic interactions against $E$. coli, Salmonella enterica, S. aureus, and Bacillus cereus were also obtained after combining clove EO $(10 \mu \mathrm{L})$ to oregano EO $(20 \mu \mathrm{L})$ through the disc diffusion technique (Pombo et al., 2018). Besides, the combination between citric and acetic acids has demonstrated higher antimicrobial potential than the application of sanitizing agents in separate (Al-Rousan et al., 2018). Based on the present study, there may have been synergism among the antimicrobial effects of the proposed substances.

Fruit biodeterioration rates change depending on samples' microbiological load after the conservation treatment (Lopez et al., 2018). High microbial counts can accelerate the run-out process caused by microorganisms; therefore, the applied process must be able to reduce the initial microbial load in order to extend the product's shelf-life. Food recontamination control or the maintenance of the initial microbiological load after sanitization can be achieved through proper packaging and storage conditions (Kang et al., 2018). Microorganisms are mostly found on food surface, but contamination by viable microbial forms can eventually happen in food inner tissues. Most fruits keep cell metabolism active after harvesting and such feature contributes to fruit run-out and to the growth of pathogenic microorganisms. Microbial contamination can cause severe changes in fruits' physiology and composition. Some fungal (Alternaria, Fusarium, Penicillium, and Aspergillus) and bacterial species (Clostridium, Pseudomonas, Erwinia, and Bacillus) hydrolyze pectin from plant tissue and cause its softening, rot and necrosis. This process features the run-out process (Lopez et al., 2018) and accounts for irreversible changes in food features such as nutrient losses (hydrocarbons, vitamins, amino acids and metals), foul odor development, and color, taste, and texture changes.

Different food types have their specific features, their internal and external tissues differ from each other; thus, sanitizers have different actions in different types of sanitized food. Plant surface influences sanitizing solution contact with microorganisms and process efficiency, since different food types present different microstructures, such as grooves, cracks, cavities, and other irregularities (São José et al., 2014). Waxy surface food, such as apples, present hydrophobic features; therefore, it can limit the food/sodium hypochlorite interaction due to its polarity. Moreover, the concentration of, and exposure time to, the sanitizing agent have straight influence on the decontamination process (Kang et al., 2018). More prominent interaction between waxy surfaces and amphiphilic solutions can favor sanitizers' antimicrobial action and so, it can justify the significantly higher reductions observed in samples sanitized with CEO in the present study.

Impact of sanitization treatments on apples' physicochemical features

$\mathrm{pH}$ (mean $=4.12 \pm 0.11$ ) and total titratable acidity (TTA) ( mean $=0.11 \% \pm 0.008$ of malic acid) in the herein investigated treatments were not significantly different from that recorded for non-sanitized samples (Table 2); this outcome evidences that these features did not change in apples.

Similar $\mathrm{pH}$ values (4.00) were previously reported for fresh apple samples (Maldonado et al., 2017). A study testing Tabule salad sanitized with acetic and citric acid (in combination or in separate) showed $\mathrm{pH}$ reduction after the sanitization process (Al-Rousan et al., 2018). Thus, assumingly, this result may be related to food structure and to how it was sanitized., i.e., if the fruit was whole or sliced at the time of sanitization. Apples have a peel that protects them from the sanitizer/ food internal structure interaction. Assumingly, the exposure of peeled food, or of food presenting weaker structures, to the sanitizing solution may favor the transference of chemical agents into their pulp.

Food $\mathrm{pH}$ concerns hydrogen ions' concentration in it; $\mathrm{pH}$ evaluation is essential to determine the microbial growth and 
Table 2. Means and standard deviation of $\mathrm{pH}$, total titratable acidity (TTA) and total soluble solids (TSS) of non-sanitized apples and of apples subjected to different sanitization treatments for 5 minutes.

\begin{tabular}{cccc}
\hline Treatment & pH & $\begin{array}{c}\text { TTA } \\
\text { (\% malic acid) }\end{array}$ & $\begin{array}{c}\text { TSS } \\
\text { ( }{ }^{\circ} \text { Brix) }\end{array}$ \\
\hline No Sanitizer & $4.04 \pm 0.32^{a}$ & $0.11 \pm 0.03^{a}$ & $12.66 \pm 0.66^{a b}$ \\
Sodium hypochlorite 200 $\mathrm{mg} \mathrm{L}^{-1}$ & $4.06 \pm 0.32^{\mathrm{a}}$ & $0.12 \pm 0.01^{\mathrm{a}}$ & $12.76 \pm 0.89^{\mathrm{ab}}$ \\
\hline Citric acid 1\% & $4.33 \pm 0.16^{\mathrm{a}}$ & $0.12 \pm 0.15^{\mathrm{a}}$ & $10.83 \pm 1.35^{\mathrm{ab}}$ \\
Clove essential oil 0.5\% & $4.11 \pm 0.98^{\mathrm{a}}$ & $0.10 \pm 0.02^{\mathrm{a}}$ & $13.63 \pm 1.26^{\mathrm{a}}$ \\
\hline Citric acid 1 \% + Clove essential oil 0.5\% & $4.09 \pm 0.95^{\mathrm{a}}$ & $0.11 \pm 0.01^{\mathrm{a}}$ & $10.70 \pm 0.88^{\mathrm{b}}$ \\
\hline
\end{tabular}

* Different letters in the same column indicate statistically significantly difference in the Tukey test $t$ at $p \leq 0.05$.

enzymatic activity of microorganisms, as well as fruits run-out potential, taste retention, odor and ripening control. TTA is an important index to evaluate the sensory quality of fruits since it results from the organic acids in the food and influences fruit flavor, aroma, color, stability and ripening.

CEO and CEO-combined treatments recorded significant differences for parameter TSS $(p \leq 0.05)$ (Table 2). This result is likely associated with sample features themselves, rather than to the treatment itself. Factors such as luminosity, ripening degree, rootstock type and crown cultivar can lead to different TSS degrees in apples. These factors would explain the herein recorded differences, since rigid fruit peels would prevent the direct action of the sanitizer in the internal structure of the food, a fact that would make it impossible incorporating and changing this parameter. The evaluation of mean features of Royal Gala $(n=120)$ and Fuji $(n=120)$ apple cultivars has led to mean values of $11.43 \pm 0.45^{\circ}$ Brix for Royal Gala apples, and of $12.68 \pm 1.82^{\circ}$ Brix for Fuji apples (Toebe et al., 2014). The TSS value recorded in the present study for the combined treatment was statistically similar to that of the non-sanitized sample and to that treated with the chlorinated compound $(p \leq 0.05)$. Therefore, the reduction observed in this parameter after the application of the combined treatment is not necessarily a negative aspect about the quality of fruits subjected to the sanitization treatment.

TSSs, mostly sugars and organic acids, play a significant role in the quality of the fruit, due to their influence on the thermophysical, chemical and biological properties of products. TSSs account for fruit taste and, consequently, for consumers' acceptance; moreover, they are fruit ripening indicators, thus, their maintenance is essential. Consumers look for microbiologically safe products that do not pose any risk to the environment or to human health. Furthermore, sanitizers must keep the quality features of food. Accordingly, the here in tested treatments have the potential to be further assessed and, likely applied in the food processing industry, due to their antimicrobial efficiency and short exposure time - which are fundamental criteria for chemical agents' use at industrial level.

\section{Evaluation of sanitizing solution $\mathrm{pH}$}

The tested sanitizing solutions recorded significant difference in $\mathrm{pH}(\mathrm{p} \leq 0.05)$ (Table 3$)$.

Controlling sanitizing solution's $\mathrm{pH}$ is essential for operation efficiency, as well as the choice for the most appropriate sanitizer for a given food type (Lepaus et al.,
Table 3. Means and standard deviation of sanitizing solution $\mathrm{pH}$ - solutions prepared and used for apples' sanitization.

\begin{tabular}{cc}
\hline Treatment & $\mathrm{pH}$ \\
\hline Sodium hypochlorite 200mg L-1 & $8.15 \pm 0.63^{\mathrm{a}}$ \\
Citric acid 1\% & $2.43 \pm 0.01^{\mathrm{c}}$ \\
Clove essential oil 0.5\% & $4.76 \pm 0.28^{\mathrm{b}}$ \\
Citric acid 1 \% + Clove essential oil 0.5\% & $2.38 \pm 0.01^{\mathrm{d}}$ \\
\hline
\end{tabular}

* Different letters in the same column indicate statistically significantly difference in the Tukey test at $p \leq 0.05$.

2020). It is essential evaluating sanitizing solution $\mathrm{pH}$, since this is a microbial survival and sanitization process effectivenessrelated parameter. Most bacteria, mainly the pathogenic ones, have difficulty to grow, or do not grow at all, at $\mathrm{pH}$ below 4.50; besides, they are sensitive to $\mathrm{pH}$ above 8.00. Therefore, the sanitizing agent can create an unfavorable environment for microorganisms and, consequently, prevent proliferation. Changes in solution $\mathrm{pH}$ are related to the sanitizing efficacy of chemicals used in food sanitation. This process may influence the stability of chemicals' compounds and the chemical agent/ microorganism interaction.

Evidence in the literature relate chlorinated solution $\mathrm{pH}$ used for sanitization to toxic halogenated disinfection byproduct formation rates, with emphasis on trihalomethanes, such as chloroform. Many cases show that chloroform concentration increases as $\mathrm{pH}$ also increases ( $\geq 8$ ) (Hung et al., 2017). The optimum $\mathrm{pH}$ for aerobic mesophilic microorganisms' growth is between 6.50 and 7.50; minimal growth is observed at values close to 4.00 . The lower the $\mathrm{pH}$ value of a sanitizing solution, the more adverse the medium for the microorganism. The $\mathrm{pH}$ variation changes the functioning of enzymes and nutrient transportation into the cell. This process can inhibit microorganisms' growth or even their death. Yeasts and mold can survive within a wide $\mathrm{pH}$ range, but still, they are sensitive to this parameter. Assumingly, the lowest $\mathrm{pH}$ value recorded for the combined treatment $(2.38 \pm 0.01)$ had greater influence on samples' microbial contamination reduction than treatments without sanitization or than treatments with sodium hypochlorite. Similar results were previously reported when the microbial inactivation effects of lactic acetic acid and chlorinated compounds, were compared (Lepaus et al., 2020).

\section{Conclusions}

All alternative treatments showed similar or better microbiological decontamination results than sodium hypochlorite application. Regarding the physicochemical 
features no significant differences were found among the treatments.

The combined treatment ( $1 \%$ citric acid and $0.5 \%$ clove essential oil) was more efficient than conventional treatment (sodium hypochlorite); whereby it could be adopted for apples' sanitization.

Of course, complementary studies are important to evaluate the sensorial impacts of these alternatives' sanitizers.

\section{Compliance with Ethical Standards}

Author contributions: Conceptualization: GLM, JFBSJ; Data curation: GLM, JFBSJ; Formal analysis: GLM, JFBSJ; Investigation: GLM, BML, JSCO; Methodology: GLM, JFBSJ; Project administration: JFBSJ; Resources: JFBSJ; Supervision: JFBSJ; Validation: JFBSJ; Visualization: GLM, BML, JSCO, Writing- original draft: GLM, BML, JSCO; Writing - review \& editing: GLM, BML, JSCO, JFBSJ.

Conflict of interest: The authors declare that they have no conflict of interests.

Funding: None.

\section{Literature Cited}

Abdollahzadeh, E.; Rezaei, M.; Hosseini, H. Antibacterial activity of plant essential oils and extracts: The role of thyme essential oil, nisin, and their combination to control Listeria monocytogenes inoculated in minced fish meat. Food Control, v.35, n.1, p. 177-183, 2014. https://doi.org/10.1016/j. foodcont.2013.07.004.

Alenyorege, E. A.; Ma, H.; Ayim, I. Inactivation kinetics of inoculated Escherichia coli and Listeria innocua in fresh-cut Chinese cabbage using sweeping frequency ultrasound. Journal of Food Safety, v. 39, n.9, e12696, 2019. https://doi.org/10.1111/jfs.12696.

Al-Rousan, W.M.; Olaimat, A.N.; Osaili T.M.; Al-Nabulsi, A.A.; Ajo, R.Y.; Holley RA. Use of acetic and citric acids to inhibit Escherichia coli 0157:H7, Salmonella Typhimurium and Staphylococcus aureus in tabbouleh salad. Food Microbiology, v.73, p.61-66, 2018. https://doi.org/10.1016/j.fm.2018.01.001.

Anuário Brasileiro da Maçã 2019. Santa Cruz do Sul: Editora Gazeta Santa Cruz, 2019. 56p.

Association of Official Analytical - AOAC. Official methods of analysis of the Association of Official Analytical Chemists. 20.ed. Gaithersburg: AOAC, 2016.

Beraldo, C.; Daneluzzi, N.S.; Scanavacca, J.; Doyama, J.T.; Junior, A.F.; Moritz, C.M.F. Eficiência de óleos essenciais de canela e cravoda-índia como sanitizantes na indústria de alimentos. Pesquisa Agropecuária Tropical, v.43, n.4, p.436-440, 2013. https://doi. org/10.1590/S1983-40632013000400006.

Chatterjee, A.; Abraham, J. Microbial contamination, prevention, and early detection in food industry. In: Holban, A.M.; Grumezescu, A.M. (Eds.). Microbial contamination and food degradation. London: Academic Press, 2018. Chap. 2, p.21-47. (Handbook of Food Bioengineering Series, 10). https://doi.org/10.1016/B9780-12-811515-2.00002-0.
Devi, K.P.; Nisha, S.A.; Sakthivel R.; Pandian, S.K. Eugenol (an essential oil of clove) acts as an antibacterial agent against Salmonella typhi by disrupting the cellular membrane. Journal of Ethnopharmacology, v.130, n.1, p. 107-115, 2010. https:// doi.org/10.1016/j.jep.2010.04.025.

Downes, F.P.; Ito, K. Compendium of methods for the microbiological examination of foods. 4.ed. Washington, D.C.: American Public Health Association, 2001.

Dunn, L.L; Harness, M.L.; Smith, D.M.; Gorman, S.J.; Zhong, Q.; Davidson, P.M.; Critzer, F.J. Essential Oil Emulsions as postharvest sanitizers to mitigate Salmonella crosscontamination on peppers. Journal of Food Protection, v.82, n.1, p.159-163, 2019. https://doi.org/10.4315/0362-028X. JFP-18-190.

Hung, Y-C; Waters, B.W.; Yemmireddy, V.K.; Huang, C-H. pH effect on the formation of THM and HAA disinfection byproducts and potential control strategies for food processing. Journal of Integrative Agriculture, v.16, n.12, p.2914-2923, 2017. https://doi.org/10.1016/S2095-3119(17)61798-2.

Kang, J-H.; Song. K.B. Combined effect of a positively charged cinnamon leaf oil emulsion and organic acid on the inactivation of Listeria monocytogenes inoculated on fresh-cut Treviso leaves. Food Microbiology, v.76, p. 146-153, 2018. https:// doi.org/10.1016/j.fm.2018.05.004.

Lepaus, B.M.; Rocha, J.S.; São José, J.F.B. Organic acids and hydrogen peroxide can replace chlorinated compounds as sanitizers on strawberries, cucumbers and rocket leaves. Food Science and Technology, v.40, suppl.1, p.242-249, 2020. https://doi.org/10.1590/fst.09519.

Lippman, B.; Yao, S.; Huang, R.; Chen, H. Evaluation of the combined treatment of ultraviolet light and peracetic acid as an alternative to chlorine washing for lettuce decontamination. International Journal of Food Microbiology, v.323, e108590, 2020. https://doi.org/10.1016/j.ijfoodmicro.2020.108590.

Lopez, M.E.S.; Gontijo, M.T.P.; Boggione, D.M.G.; Albino, L.A.A.; Batalha, L.S.; Mendonça, R.C.S. Holban, A.M.; Grumezescu, A.M. (Eds.). Microbiological contamination in foods and beverages: consequences and alternatives in the era of microbial resistance. In: Microbial contamination and food degradation. London: Academic Press, 2018. Chap.3, p. 49-84. (Handbook of Food Bioengineering Series, 10). https://doi. org/10.1016/B978-0-12-811515-2.00003-2.

Maldonado, R.R.; Castilho, T.G.; Brandini, M.T.; Deziderio, M.A.; Aguiar-Oliveira, E.; Kamimura, E.S. Aplicação de biofilme comestível em maçãs minimamente processadas armazenadas sob refrigeração. FOCO: Caderno de Estudos e Pesquisas, n.10, p.60-80, 2017. http://www.revistafoco.inf.br/index.php/ FocoFimi/article/view/88. 19 Mar. 2020.

Marques, C.S.; Grillo, R.P.; Bravim, D.G.; Pereira, P.V.; Villanova, J.C.O.; Pinheiro, P.F.; Carneiro, J.C.S.; Bernardes, P.C. Preservation of ready-to-eat salad: A study with combination of sanitizers, ultrasound, and essential oil-containing $\beta$-cyclodextrin inclusion complex. LWT - Food Science and Technology, v.115, e108433, 2019. https://doi.org/10.1016/j. Iwt.2019.108433. 
Oulkheir, S.; Aghrouch, M.; El Mourabit, F.; Dalha, F.; Graich, H.; Amouch, F.; Ouzaid, K.; Moukale, A.; Chadli, S. Antibacterial activity of essential oils extracts from cinnamon, thyme, clove and geranium against a gram negative and gram positive pathogenic bacteria. Journal of Diseases and Medicinal Plants, v. 3, n. 2-1, p.1-5, 2017. https://doi.org/10.11648/j. jdmp.s.2017030201.11.

Park, S-H.; Choi, M-R.; Park, J-W.; Park, K-H.; Chung, M-S.; Ryu, S.; Kang, D-H. Use of organic acids to inactivate Escherichia coli 0157:H7, Salmonella Typhimurium, and Listeria monocytogenes on organic fresh apples and lettuce. Journal of Food Science, v.76, n.6, M293-M298, 2011. https://doi. org/10.1111/j.1750-3841.2011.02205.x.

Poimenidou, S.V.; Bikouli, V.C.; Gardeli, C.; Mitsi, C.; Tarantilis, P.A.; Nychas, G.J.; Skandamis, P.N. Effect of single or combined chemical and natural antimicrobial interventions on Escherichia coli 0157:H7, total microbiota and color of packaged spinach and lettuce. International Journal of Food Microbiology, v. 220, p.6-18, 2016. https://doi.org/10.1016/j. ijfoodmicro.2015.12.013.

Pombo, J.C.P.; Ribeiro, E.R.; de Lima Pinto, R.; Silva, B.J.M. Efeito antimicrobiano e sinergístico de óleos essenciais sobre bactérias contaminantes de alimentos. Segurança Alimentar e Nutricional, v. 25, n.2, p.108-117, 2018. https://doi. org/10.20396/san.v25i2.8651785.

São José, J.F.B.; Medeiros, H.S.; Bernardes, P.C.; Andrade, N. J. Removal of Salmonella enterica Enteritidis and Escherichia coli from green peppers and melons by ultrasound and organic acids. International Journal of Food Microbiology, v.190, n.1, p.9-13, 2018. https://doi.org/10.1016/j. ijfoodmicro.2014.08.015.
Siroli, L.; Patrignani, F.; Serrazanetti, D.I.; Vernocchi, P.; Del Chierico, F.; Russo, A.; et al. Effect of thyme essential oil and Lactococcus lactis CBM21 on the microbiota composition and quality of minimally processed lamb's lettuce. Food Microbiology, v.68, p.61-70, 2017. https://doi.org/10.1016/j.fm.2017.06.017.

Tian, J-Q.; Bae, Y-M.; Lee, S-Y. Survival of foodborne pathogens at different relative humidities and temperatures and the effect of sanitizers on apples with different surface conditions. Food Microbiology, v.35, n.1, p.21-26, 2013. https://doi.org/10.1016/j. fm.2013.02.004.

Toebe, M.; Both, V.; Thewes, F.R.; Cargnelutti, Filho, A.; Brackmann, A. Tamanho de amostra para a estimação da média de caracteres de maçã. Ciência Rural, v.44, n.5, p.759-767, 2014. https://doi. org/10.1590/S0103-84782014000500001.

Veloso, R.J.; Fronza, N.; Vargas Júnior, A.; Carvalho, V. S.; Fujinawa, M.F.; Silveira, S.M.da. Potential of thyme essential oil on arugula sanitization. Ciência e Agrotecnologia, v.43, e006819, 2020. https://doi.org/10.1590/1413-7054201943006819.

Wang, C.; Chang, T.; Yang, H.; Cui, M. Antibacterial mechanism of lactic acid on physiological and morphological properties of Salmonella Enteritidis, Escherichia coli and Listeria monocytogenes. Food Control, v.47, p.231-236, 2015. https://doi.org/10.1016/j. foodcont.2014.06.034.

Wang, C.; Chang, T.; Yang, H.; Cui, M. Surface physiological changes induced by lactic acid on pathogens in consideration of $\mathrm{pKa}$ and pH. Food Control, v.46, p.525-531, 2014. https://doi. org/10.1016/j.foodcont.2014.06.024.

Weng, S.; Luo, Y.; Li, J.; Zhou, B.; Jacangelo, J. G.; Schwab, K. J. Assessment and speciation of chlorine demand in fresh-cut produce wash water. Food Control, v.60, p.543-551, 2016. https://doi.org/10.1016/j.foodcont.2015.08.031. 